\title{
WHY DO WE CARE ABOUT POST-HUMANISM? A CRITICAL NOTE
}

\author{
by \\ Bo Allesøe Christensen
}

\begin{abstract}
CHRISTENSEN, B. A. (2014): 'Why do we care about posthumanism? A critical note', Geografiska Annaler: Series B, Human Geography 96 (1): 23-35.
\end{abstract}

\begin{abstract}
What is disclosed in the questioning of the human being in post-humanism? Addressing this question in congruence with Heidegger's questioning of being in Being and Time, we end up with two discoveries: first, that the characteristic of Dasein, as the being of the questioning, already carries the same implications as the post-human figure, and second, that questioning in this sense is indicative of the effort of realizing a new scientific space for conceptualizing the human being as non-substantialist. Conceived of in this way, however, post-humanism is a result of a very human effort indeed.
\end{abstract}

Keywords: post-humanism, Martin Heidegger, question of being, responsive responsibility

Die Philosophie ist eigentlich Heimweh, ein Trieb überall zu Hause zu sein.

\section{Novalis}

\section{Introduction}

The post-human figure figures prominently in contemporary human geography, and has done so for a while. It is also 'a fraught entity, for we seek to fix it even as we dissolve it' (Braun 2004a, p. 269). Be it in the form of a search for 'the figure of the human' itself - 'its fixing and bounding' - or 'the emergence of the human, the human as project and practice, the body as an outcome of the "infolding" of the world", or something that 'extends far beyond us, and that is not of our making alone' (Braun 2004a, p. 273, italics in the original), the anthropocentrism of our time and the hubris of humanism have been challenged by the emergence of non-representational theory, actor-network theory and other influential bodies of thought. The question is, however, how post human this figure actually is?

In a sense, this goes to the very heart of the discipline, addressing as it does the human in human geography. Yet, putting the human in its place by downsizing or dethroning it is not a straightforward affair. As Cadman (2009, p. 136) suggested by referring to Castree and Nash (2006), the positing of the idea of post-humanity as a historical condition faces the fear of actually reinstalling what it seeks to overcome, namely the human as a stable and coherent category. This annoying dialectic can be specified as follows (see Braun 2004a, p. 271). "We", the post-humans, are now, finally, in a historical position capable of understanding human being as fundamentally entangled with non-human being. Humans subjected to xenotransplantation, or living with technology as part of their bodies, exemplify different human-non-human assemblages. As Braun (2004a, p. 271) claims, both the figure of and the making of the human are challenged here, the former by questioning where the line between the human and the non-human is drawn, the latter by challenging an ontology where being human is defined by sharing some core substance. Instead our "humanness" is continuously changing in conjunction with our immediate surroundings, leaving no clear defined human figure or essence to be found. Post-humanism, hence, implies non-anthropocentrism (Braun 2004a, p. 272), that the world studied, and particularly the social one, is comprised of non-human entities and agents as well, giving no pride of place, no exception, to human being.

Being in a post-human age, in distinction from a previous age with boundaries between human and non-human sustained, creates, dialectically, a problem. Distinguishing between a post-human and a human age requires of the post-human age that it defines itself up against the previous age. Posthumanism thereby reinstalls the necessity of what it questions the existence of, namely the human. Cadman's (2009, p. 137) study shows, then, through analysing, "the historical conditions of existence for the very questioning of the human and the nonhuman distinction itself' that an idea of the human is not, contrary to what post-humanists seems to think, as easily dispensed with.

Another example of questioning posthumanism is the disquiet thought that post-human thinking exaggerates the denouncing of the human being. Here are some excerpts from a recent 
conference including a session entitled 'Human remains: the place of the human in a post-human world' (Harrison and Wylie 2011):

This session asks: what remains of the human after successive waves of anti- and post-humanist thinking? What has been lost and what, if anything, is worth saving? Is it possible or indeed desirable to offer a defence of the human? ... from Freud's suspicions and Marx's materialism at the start of the twentieth century, to Adorno and Horkheimer's critique of the Enlightenment, Foucault's and Barthes' death of the author ... the figure of the human has been subject to decentring and displacement, dethroning and flattening; its outline fading; its gestures magnetised and its consciousness little more than a synaptic symptom. Perhaps now it is time to move on, to find different ways of framing and thinking about (and organising and cultivating) subjectivity, sociality, politics and responsibility?

Finding a new way of framing and thinking about the human way of being might involve saving, or at least retrieving some possibility of being human otherwise lost in post-humanism. Questioning the idea of post-humanism, then, is expressing a concern for whether the post-human ontology is capable of incorporating some remains worth saving (whatever they are) of our understanding of human being. Both Cadman and the session proposal seems to be questioning the post-human ontology, without claiming the necessity of reinstating any "good old days and ways" of the human on top of things. Instead they are expressing a sense of unsettledness regarding the remains of some human way of being, hence a concern for conceiving humans as part of this allegedly new ontology.

This article is a small contribution to this questioning of post-human ontology, albeit with a slightly different point of departure. First, the above two examples could be interpreted as disclosing a connection between the questioning of any ontology and our self-understanding as querying human beings. Correspondingly, a scientific endeavour of inquiring, or investigating, is a process expressing the understanding of scientists as well. The concern expressed in the examples above might then be characterized as querying the possibilities of understanding ourselves as scientists and as human beings within a post-human ontology. What this self-understanding could amount to, then, will be one object of scrutiny below. The importance of clarifying this self-understanding by reinvigorating a somewhat old discussion of the post-human (Castree et al. 2004) might seem superfluous, but, as already claimed, it is highly relevant since a posthuman condition is presupposed in many current theoretical trends, like non-representational theory (Thrift 2008, p. 222, for example, speaks of a posthuman agenda, where the entanglements between human and non-human beings is the primary interest). Hence, analysing what the consequences of this, perhaps uncritically adopted, general presupposition of post-humanity amounts to, is both a legitimate and necessary part of scientific reflection.

Second, to unravel this presupposition of posthumanity we will turn to one of the prime sources of inspiration, perhaps the instigator, of posthumanism, namely Heidegger, drawing on his early (Sein und Zeit, Heidegger's 1927 work) thinking as a significant perspective for understanding posthumanism. This will be productive for several reasons. First, Heidegger captures, by posing the question of what "being" means anew, the connection between questioning ontology and understanding human ways of being in all their complexity. Thus, Heidegger's thinking can help advance the understanding of what is involved in questioning the post-human ontology as a scientific endeavour. This is in line with recent interpretations of Heidegger (Haugeland 1999, 2013; Rouse 1999, 2002, 2005; Carman 2003), emphasizing his contribution to both a general understanding of scientific practices, and to human geography in particular (e.g. Paddock 2004; Elden 2005; Malpas 2006; Sayer 2011; Simonsen 2013; recent contributions include e.g. Hannah 2013 and Olwig 2013 in this journal). The practical import of an entity like the post-human, then, is expressed in scientific debating of this entity, and the concern for understanding the concomitant ontology.

Second, Heidegger's overall goal is, as Grondin (2005, p. 15) claims, 'always to call thought and existence back to their essential question, the question of Being.' Part of this calling back is Heidegger's questioning the received opinion of what a human being is. One thematic focus uniting early and late Heidegger, then, is the critique of anthropocentrism, or anthropologism as Dastur (2000) expresses it. This is a critique 'aimed at showing that the traditional conception of man as a separate being cannot allow the being-question to be raised' (Dastur 2000, p. 126). So, instead of conceiving the human being 
- or Dasein as Heidegger terms it - as a separate entity, or substance, it is understood as the place, the $D a$, for (where) being, sein, to (could) disclose itself. ${ }^{1}$ Conceiving the human being in terms of a separate substance, then, presupposes a concept of the human as detached from the surroundings, blocking an inquiry into whether this actually is so. So, Heidegger was a precursor to and, as Rae (2010, p. 25) puts it, played a significant part in laying 'the foundation for the so-called "anti"-humanism of structuralist, post-structuralist and deconstructionist thought, and, more contemporarily of debates relating to the posthuman'.

As a consequence, it can be argued that both historical and thematic reasons exist for justifying a juxtaposing of these Heideggerian topics (questioning ontology and a critique of a substantialist perspective of human being) with the post-humanist themes already addressed, and with the case-study of this article, the debate between Badmington, Braun, Murdoch and Whatmore (Castree etal. 2004). The specific focus, however, will be the implications of Heidegger's questioning the meaning of being, and not the detailed analysis he conducts, ${ }^{2}$ and this will show two things. First, a generous interpretation of Heidegger's concept of being in the world seriously questions the novelty of posthumanism. Heidegger's understanding of questioning being as implying an understanding of entities already embedded in the world (including ourselves) establishes a primary entanglement between human and non-human entities conceived in a non-substantialist and non-exceptionalist fashion. Furthermore, this entanglement serves as a meaningful basis for the possible conceptual differentiating and identifying of human, post-human and non-human entities. Second, scientific practices, including research on the notion of post-humanism, are, within the processes of understanding new aspects of the ontology, disclosing some sense of responsible responding towards these new aspects. This responding, then, denotes a very human concern or caring for a proper understanding of the ontology of which researchers are part as well.

\section{Questioning essences and identities: modalities of post-humanism}

Castree and Nash's (2004) description of three, more or less, connected modalities of post-humanism is useful as a general characteristic. The first modality sees post-humanism as an incipient historical condition, where post signifies a decisive temporal break from an exclusively human-centred history. As claimed in the introduction this is not, in the prevailing description, post human at all. Thus, the remaining two is of more interest.

The second modality sees post-humanism as identifying 'a set of ontological theses about the human that never was and will never be' (Castree and Nash 2004, p. 1342). Unlike the first modality no historical break is assumed here, instead it is recognized that the concept human is an idea never to be realized. Paraphrasing the title of one modern classic (Latour 1993), this idea could be expressed as we have never been human - no a-historical substance satisfying the criteria of being human either exists, or will ever exist. Under this heading the different critiques of a substantialist and self-transparent human subject connected with post-structuralism and post-modernism is subsumed. Haraway's cyborgs or the actants of actor-network theory could exemplify the non-substantialist character of being human here.

Related is the third modality unfolding a 'ceaseless scepticism about the claims made in the name of either the human or its notional transcendence' (Castree and Nash 2004, p. 1342). Under this heading fall two aspects. First, what Appleby (2010) denotes a critical stance towards anthropocentrisms like human exceptionalism, thereby denouncing the alleged superiority of the human in comparison to other entities. Second, the critique of any defining of the human being or its Other, like nature, animals, technology, or such like, in terms of a difference between the two. Defining identities this way presupposes in the end, it is claimed, a reliance on some clearly defined binary opposition, like nature/culture, human/animal or inner/outer, all losing their definitional certainty and clarity when scrutinized further.

The two last modalities express, in the words of Castree and Nash, an analytical-philosophical position based on an expanded ontology as point of departure. Expanded in the sense of Whatmore's expression of the "messy heterogeneity of being-in-theworld' (Whatmore 2002, p. 147; Badmington 2004, p. 1345), following the dissolution of previously secure and fixed distinctions between human and non-human, and replacing substances with a sense of becoming instead. As Castree and Nash (2004, p. 1342) recapitulate, 'In all this, whether there is anything specific about the human to be defended, supplemented, or erased is an open question.' The 
importance of addressing post-humanism, then, depends upon a commitment making scientific practices like 'human geography less resolutely human' (Castree and Nash 2004, p. 1343), or, implying this is an open question, not.

Notice here that defending, supplementing or erasing presupposes - probably not intentionally the same object of attention: the human. However different, even antithetical, these attitudes are, their explorations seem to agree on what to behold, hence, seems to be sharing the same, or parts of the same, ontology. So, the concept of the post-human, or post-humanity, it seems, possesses a significant relation to the human, as that which is not primarily human or what comes after the human. As Murdoch (2004, p. 1357) notes, then, the more distinguishing humanism from post-humanism is insisted on, the more they seem to become entangled. Whatmore (2004), in an argument similar to the one stated by Cadman and Braun and reiterated in the introduction to this article, makes the same observation. For Whatmore, exceeding the human rather than posthuman is a more accurate description of a "morethan-human" ontology. Disconnecting any time relation like before and after the human within this ontology, 'one never arrives at a time/place when the human was not a work in progress' (Whatmore 2004, p. 1361), she claims.

These characterizations of post-humanism, including the more-than-humanness, are all expressions of attitudes in an investigative mode like reckoning, beholding or pondering what post-human being is or is not, more than an understanding of what it means. Hence, the scientific comportment towards the object of scrutiny is, in Heidegger's terminology (Heidegger 1927, p. 11, 1962, p. 31), more of an ontic than an ontological kind. An ontic investigation studies entities and their categories, concentrating on how to characterize these entities or not. ${ }^{3}$ The ontological investigation, however, asks about these entities' ways of being, how entities are understood as entities, like understanding post-human being as post-human. So, inquiring ontologically is connected to a mode of being where some kind of understanding is presupposed, before any ontic characterisation and conceptual determination can take place. As Heidegger claims, 'An understanding of Being is already included in conceiving anything which one apprehends in entities' (Heidegger 1927, p. 3, 1962, p. 22). As opening a car door is usually just done, that is, understood meaningfully without pondering the existence of or nature (substance) of the door handle, so the concept of the post-human presupposes an understanding on the basis of which researchers already somehow engage with the world.

A critique of a specific cognitive way of conceiving the relation between the human subject and the world is implicit here. Understanding something is not primarily an effect of a relation of detachment between an observer and something observed. Rather, it is the significance disclosed in the practical circumstances where the observer and observed are engaged with each other. This, however, is not tantamount to understanding the practical and theoretical, or engaged and detached, as 'two separate and distinct ways of being-there [Dasein, BAC], but that being-there is itself such as to support different possible modes of disclosure, and that those modes are always underlain by a more basic gatheredness of being-there and world' (Malpas 2006, p. 141). Understanding what the significance of a door handle is, is not, in the first place, achieved by looking at it. Rather, the understanding is reached by using it to open a door as part of the overall significance (of the practical circumstance) of entering a car, doing what one does with cars (Malpas' gatheredness as the entanglement of Dasein and the car disclosing the world, the significance, of driving). Subsequently, Dasein might ponder, or inquire theoretically, what this door handle is made of, how it could look and so forth. But the ostensible world-constituting capacities and generative achievements connected to this objectifying ontic attitude are always underlain by the practical 'situated life-projection of a factical being that finds itself in the world - Dasein' (Habermas 1989, p. 437). And it is this connection between the projecting of meaning and finding one self in the world which is disclosed in Heidegger's questioning of being. Furthermore, the connection is crucial for understanding both Heidegger's non-substantialist understanding of human being, and the concern expressed in the research of the post-human, or morethan-human, figure.

\section{Questioning post-humanism: Heidegger's questioning of being}

According to Heidegger, comportments (scientific, theoretical, practical, etc.) towards understanding the surrounding world, including people, has, predominantly, been characterized by a focus on entities and the presumed (thing-like) substances of these entities, instead of the being of these entities. 
The proposed questioning of being introduced in the beginning of Being and Time, is supposed to remedy this predicament, by reawakening this forgotten question (Heidegger 1927, p. 2, 1962, p. 21). ${ }^{4}$ Furthermore, it is a theme running through all of Heidegger's thinking, early and late, albeit with different accentuations of the implications of this questioning.

Three premises are important for understanding the importance of Heidegger's questioning of being. First of all, Heidegger claims that an analysis of Dasein is needed as part of this questioning. This, however, is not entailing that Being and Time is a regular work of anthropology. On the contrary, Heidegger notes that any questioning presupposes some understanding of what is being questioned; otherwise the direction of the questioning will be blind. Hence, questioning being must start with some previous understanding, however vague or un-thematic it turns out to be, and Dasein is the only being who has some kind of understanding in this initial sense. Dasein's understanding should be accepted as a point of departure, then, but without implying, a priori, any substantial claims about Dasein. Second, being is not an entity (Heidegger 1927, p. 6,1962, p. 26). There is a difference between an entity, like a hammer, and its being, hammering, which can be done for a number of different purposes. This means that even though entities exist independently of Dasein, in disclosing these entities' being Dasein is somehow involved, what Malpas in the quote above termed the support of Dasein (see Cerbone 1995 for a discussion of this realism and idealism by Heidegger). Third, being is always the being of an entity (Heidegger 1927, p. 9, 1962, p. 29) This might sound odd due to the first premise, but there is nothing peculiar about it. The being of the hammer is not given by some transcendent entity, say a hammer god upholding the existence of hammers, or by reducing the hammer to its material compounds. Where the former borders on superstition, to say the least, the latter may be accepted, but it really says nothing about the being of the hammer, only what it is made of - the hammer could be made of glass, which obviously makes it much less suitable for being a hammer.

According to Heidegger (Heidegger 1927, p. 42, 1962, p. 68), then, Dasein is the only entity for whom being, including its own being, can be of a concern; therefore 'sciences have the manner of Being which this entity - man himself - possesses. This entity we denote by the term Dasein' (Heidegger 1927, p. 12,
1962 p. 32) Uncovering what is involved in questioning and understanding the meaning of being, then, attention to how this matters within the scientific practice would be needed, that is, how a posthuman ontology is of Dasein's concern, for example through the debating or exploring of new research agendas. Furthermore, both a highly theoretical entity like this post-human figure and the practical engagement of researching this entity is somehow disclosed through explicating Dasein's being.

As claimed in the last section, research on posthumanism is predominantly of an ontic concern. To investigate the post-human being, then, is to determine what it is, or is not, like the negative determination Badmington (2004, p. 1345) proposes:

As I understand it, humanism is a discourse which claims that the figure of "Man" (sic) naturally stands at the centre of things; is entirely distinct from animals, machines, and other nonhuman entities; is absolutely known and knowable to "himself"; is the origin of meaning and history; and shares with all other human beings a universal essence. Its absolutist assumptions, moreover, mean that anthropocentric discourse relies upon a set of binary oppositions, such as human/ inhuman, self/other, natural/cultural, inside/outside, subject/object, us/them, here/there, active/ passive, and wild/tame.

What would be missing here, according to Heidegger, is the ontological understanding presupposed by this conceptual determination. This entails a shift in perspective from determining what this post-human being is not, to how this is expressing the understanding of something that matters in scientists' ways of being. As Heidegger (Heidegger 1927 , p. 6, 1962, pp. 25-26) puts it, 'In the question which we are to work out, what is asked about is Being - that which determines entities as entities, that on the basis of which entities are already understood'. The unsettledness noted in the introduction, and Whatmore's uneasiness about using the concept of the post-human instead of more than human, are responses to and indications of this presupposed understanding of being. They indicate the ontological significance presupposed by the discovery of an ontic phenomenon like the post-human, where the condition of possibility of this significance is, as Haugeland (1999, p. 47) claims, not the disclosing of a specific entity but disclosing the being of this entity. 
So, as claimed in the introduction, Heidegger's Seinsfrage is worth exploring here and inspired by Haugeland (1999) and Rouse (2002, 2005), the process of questioning will be described in two steps. The first will address why discovering (like the ontic attitude of reckoning) presupposes disclosing (an already given understanding of being), and the second will address why any disclosing of entities cannot be separated from the self-disclosing of Dasein. The first step amounts to asking how the understanding of this discovered post-human figure occurred. The second asks what is thereby disclosed about the scientific practices researching and questioning the post-human ontology.

\section{Disclosing entities}

Part of why discovery presupposes disclosing has already been registered claiming the intrinsic connection to the primary entanglement between Dasein and the world of the scientific theoretical and practical understandings respectively. Heidegger addresses this by describing how Dasein's comportments towards entities emanate from the background of already being in the world (Heidegger 1927 , p. 53,1962 , p. 78$).{ }^{5}$ Heidegger thereby emphasizes Dasein's practical and theoretical comportment towards entities as embedded and depending upon different settings or contexts. Disclosing, then, is, generally speaking, Dasein's making sense of those entities, within these settings.

As an illustration, take the game of chess. Understanding, or making sense of, the different pieces in the game, like discovering which piece is relevant to move, is intelligible only on the basis of the chess game as a whole, its overall significance. This idea is implied by the already stated claim that being is not itself an entity, like chess pieces having a being predicated on them, instead of being disclosed in their actual and possible use. ${ }^{6}$ The individual pieces of the chess game make sense, that is, can be understood as the chess pieces they are, only within the functional context of playing chess. A context implying both what the chess game is for, winning or teaching for example, the setting of the game, perhaps a tournament in front of an opponent with an audience watching, and what is used to carry out the activity, a board, the pieces, a clock. Hence, the situated environment of a chess player, beginner as advanced, and the possibilities this environment affords, 'incorporate the activities of other agents as partially reconfiguring their shared surroundings'
(Rouse 2002, p. 21). Implicit is, of course, that this reconfiguring happens differently depending on the various agents involved, like beginners, experts, clocks, missing pieces, and so forth.

People being taught how to play chess, then, have initially more of an ontic understanding of chess. They are learning to use the bishop as bishop within the functional world of chess. ${ }^{7}$ In this sense, the chess beginner's manner of playing is more characterized by discovering (the being of) chess by learning the rules for moving each individual chess piece, first as separate from the actual game playing (perhaps a trial game), and then, gradually, as direct moves within the game. The expert chess player, however, responds fluently to the playing by understanding possible kinds of moves, telling which move is the best, thereby disclosing what chess is and can be all about. ${ }^{8}$ Furthermore, the moves can be analysed by other chess experts taking up a theoretical comportment towards this particular chess game. Generally, though, there is no analysing, reckoning, learning or discovering what these individualized and thing-like objects called chess pieces are as chess pieces, apart from understanding their being as disclosed in the game of chess. They can, of course, be used for other activities, but then their meaning is disclosed as something else, not as chess pieces - compare throwing a chess piece to moving it on a chessboard even within a chess game. So, discovering what chess pieces are depends in the end on disclosing and understanding the possible ways the chess pieces can be used within a game of chess. Already being in the world (of chess), means being with other entities (humans, pieces, clocks, boards), responding to these doing what one does (playing this game, anticipating other possible games, clocks stopping, pieces tipping). Bluntly put, then, there is no essence to chess, but different ways of enacting chess games.

Appropriating Heidegger's claims, then, means understanding the ontic discovery of the posthuman has, as a condition, the disclosing of scientific practices as enacted within a world, among other entities, with a pre-given relationship between humans and non-humans. To use the hammer example again, in a significant context of hammering the relationship between the hammer and the arm, is such that there basically is no telling whether the arm functions as an enhanced hammer, or the hammer functions like an extended arm. So, although the post-human figure is not an entity like a chess piece, its discovery - the ontic comportment towards the 
post-human figure - still presupposes a meaningful context, an entanglement between human and nonhuman, wherein using the concept of post-human makes sense. A meaningful context making it available for use and supplying this use with a role; that is, describing a condition wherein a use of the concept human is inadequate.

As the expression of an ontic understanding, however, the post-human is also just a discovery of the other side of being human. The side were humans are not at the centre, have no control or substance and are not separate from other (non-human) entities in practice, rather than the disclosing of an ontology without any significance tied to human being at all. Dasein is, as being in the world, already among and related to other entities, before any conceptual determinations, such as human/post-human and so on, makes sense, and hence before any practical or theoretical comportments towards the posthuman figure can be instituted. Similar to the chess beginner, then, discovering the post-human also indicates learning how to navigate in a scientific practice enacted among other entities. The worry and uneasiness already touched upon are responses to this being in the world, as if post-human ontology meant without any human being, or without the support of Dasein at all. However, any ontology, including the post-human, depends, for its disclosing, upon Dasein as being in the world occupying a specific place where this disclosing makes sense. ${ }^{9}$

The first conclusion, that the post-human figure only makes sense on the background of Dasein already being in the world, may sound trivial, but for two reasons it is not. First, it is a result of interpreting the post-human by connecting it to Heidegger's questioning of being, thereby explicating what was previously understood as only implicit. As Heidegger (1927, p. 148, 1962, p. 188) puts it, 'In interpretation, understanding does not become something different. It becomes itself'. In German, interpreting is called aus-legen - literally laying out or putting forth - and as Caputo (1982, p. 358) claims, interpreting 'provides this prior understanding with the words with which to come into language, in so doing, it brings us to stand in the place which we already occupy'. Questioning the meaning of the post-human figure articulates the implicit understanding of already being in the world, entangled with non-human beings. Second, this implies that the idea of post-humanism is not that innovative in comparison with Heidegger's concept of being in the world. Thought through, the implication of conceiving Dasein as being in the world is the inability to understand Dasein by any substantialist modus primarily, since the entanglement makes any identification problematic (i.e. the hammer-arm example above). Any distinctions are meaningful as distinctions only on this background of being entangled, and this - as will be seen in the next section - is connected to a laying out of possible ways of being and not a reproducing of the already given.

Furthermore, when Heidegger claims that Dasein's essence is its existence, Dasein has no substantial essence, like a core of being, but exists as a possible way of being and acting. So, just like a transformation of the meaning of the chess pieces occurs, from an object-like mode of being in learning their significance towards their being used (Heidegger 1927, p. 61, 1962, pp. 88-89), the chess player's mode of being is transformed from a human being for whom the correct use of the separate chess pieces is an issue, towards being a player playing the game. Hence, the disclosing of something is at the same time a disclosing of Dasein. So what is disclosed about the scientific practice when questioning the post-human?

\section{Dasein - disclosing as self-disclosing}

In questioning being a primary practical ontological understanding has been disclosed so far, an understanding before any objectifying or other derivative ontic understanding occurs. Now, from the previous section it should be clear that being in the world, as Dasein, is not being a kind of substance understood as 'an entity which is in such a way that it needs no other entity in order to be' (Heidegger 1927 , p. 92, 1962, p. 125). Dasein is already being in the world, engaging in different meaningful practices with entities (Heidegger 1927, pp. 5657, 1962, p. 83). Heidegger captures this further by claiming that the essence of Dasein consists in its existence (Heidegger 1927, p. 117, 1962, p. 152), and that Dasein understands itself in terms of this existence (Heidegger 1927, p. 12, 1962, p. 33). So, by engaging in different practices Dasein forms an understanding of what it means for it to be engaged in these practices. This may sound obvious, but it involves a very important sense of modality, 'As understanding, Dasein projects its Being upon possibilities' (Heidegger 1927, p. 148, 1962, p. 188). The possibilities disclosed through the chess player's game, at the same time disclose the possibilities this particular chess player has for continuing 
being a chess player. Loosing, winning or a drawn game each discloses possibilities for understanding future ways of being, as laying out possible action space(s) for this chess player's way of being in the chess world and understanding hereof.

However, as Rouse (2005, p. 126) claims, when it comes to scientific practices it is important to recognize that the idea of possibility is not one of possible actualities, in other words, possibilities in the form of objects, relations and so on which might have obtained but actually do not, but 'actual possibilities (an orientation toward definite but not fully determinate ways for us to be)'. What distinguishes possible actualities from actual possibilities is that actual possibilities matter, 'They express a practical configuration of a situation such that there is something at stake in whether and how these possibilities are to be realized' (Rouse 2002, p. 25). What is at stake in our scientific practice of debating posthumanism, then, is the responsibility of getting "things" right, of disclosing the most adequate ontology, and this is tied to how 'Science discloses not objects or laws independent of us and our concerns, but phenomena that we are part of' (Rouse 2002, p. 331). Hence, the scientific endeavour is dependent on a concern and responsibility for this disclosing; disclosing as self-disclosing is being responsible, that it matters to us.

The meaningful possibilities which Dasein projects its being onto, its thematizations, are possible ways for it to be and act. For example, doing research involves diverse comportments towards different entities like students, lessons, power points, research questions or administrative project managers. Thus, sciences are 'contextually integrated in multiple ways' as Rouse (2002, p.165) claims. Being a researcher means knowing how to deal with all of these entities as part of one's work. So, Dasein's understanding of its own being presupposes an understanding of the entities among which it works. As a consequence, then, it is part of Dasein's projecting of possibilities that it is capable of projecting the possibilities of these as well. So, "neither selfunderstanding nor understanding of being is possible except insofar as they are integrated with one another' (Haugeland 1999, p. 59).

This understanding, or apprehensiveness, Heidegger (1927, p. 192) sums up by characterizing the being of Dasein as caring, that is, '(living) ahead of itself as always already being in the world as being with (entities within this world)'. ${ }^{10}$ This characterization is Heidegger's "formula" for answering why the disclosing of entities is at the same time a disclosing of Dasein. It is termed caring because it describes the fundamental openness of Dasein's comportments towards entities as being in the world. As existing, Dasein lives ahead in the sense of projecting meaning onto its future ${ }^{11}$ possibilities of being and doing. This projection, on the one hand, is not tantamount to a voluntarism or decisionism, that is, a pure exercise of Dasein's will (Dastur 2000, p. 123; Thomson 2004, p. 466), since it presupposes the facticity of already being within the world among other entities: 'Existentiality is essentially determined by facticity' (Heidegger 1927, p. 192, 1962, p. 236). ${ }^{12}$ This determination, on the other hand, is not tantamount to claiming that Dasein as such is just an effect caused by its being in the world, either. Rather, it is claiming that the accountability attached to Dasein's projections of meaning is, as expressed by Rouse above, something at stake within the scientific practice, something bigger is going on in Dasein's engaging in and with the world. At stake in the sense that what is disclosed constitutes something authoritative, something that matters, over the scientific sayings and doings of which Dasein is accountable. The self-disclosing of Dasein, within a scientific practice, then, is characterized as an 'ongoing resilient adaption of scientists' understanding to account for newly discovered phenomena, entities, or features that characterize their disclosure of the world' (Rouse 2002, p. 337). This adaption Rouse (2002, pp. 342-343) also terms a responsible responsiveness. It is responsive in the sense of being open to what emerges in the disclosing, and it is responsible in the sense that it matters for the actual possibilities of future doings and sayings in the scientific practice.

However, caring or responsible responsiveness is, as a relation between being in and projecting, not a harmonious alignment per se. As Capobianco (2005) claims, Dasein exists in a gap between actuality and possibility, between facticity and projectivity, and Heidegger expresses this by saying that Dasein is not feeling at home in the world (Heidegger 1927 , p. 188,1962 , p. 232), Dasein is primarily unsettled. The possibility of feeling at home genuinely exists, but there is no guarantee that settledness will be reached, or if it does, this settledness is permanent. The lack of guarantee is a result of Dasein's incomplete control when it comes to projecting a future space of being and doing, since it depends, in the end, on the world in which it finds itself embedded as well. The unsettledness, then, shows Dasein 
as anxious about being in the world as such, worrying whether the aims and understandings will be met through the anticipated possible way of being and doing, or losing the "world" will be the outcome instead.

Put less poetically, this might be recognized as a sense of uncertainty also part of engaging in a scientific process (Clegg 2010), and indicated in the conference proposal referred to in the introduction, as something lost. If this is plausible then, as Thomson (2004, pp. 456-457) claims, responsible responsiveness indicates a movement where the uncertainty, or unsettledness, becomes certainty directed. The broken grip the world had upon us is, therefore, responded to in such a way that it restores our grip upon the world in a responsible fashion. In other words, the world lost by being disclosed as unlike Dasein's anticipation (e.g. research results showing something completely different than anticipated), is regained by responsible responding to what matters for the future doings and saying of Dasein, as being in the world (accepting upon double or triple check that the results are genuine, and planning/projecting new research upon this). The uncertainty, of course, accompanies the certainty as new unsettling questions present themselves in the same process where other questions are settled. Now, after these excursions let us return to the post-human debate and use Heidegger's thoughts to give a different interpretation on what is involved, that is, a concern for restoring a place for understanding what it means to be human within a post-human ontology.

\section{Post-humanism as an expression of human concern}

But first, let us recapitulate. First, beneath the apparent reification of the post-human figure, a picture of Dasein as being in the world was disclosed. This is a picture claiming that the human being is, first of all, fundamentally entangled in a non-substantialist fashion, with world, and second, the place where a meaningful understanding of being can appear. One consequence was that as conceptual determinations, human and post-human being expressed different, albeit connected, ontic understandings of this fundamental being in the world. Already being in the world is the necessary condition for determining and identifying entities as different from human beings, which is, furthermore, connected to projecting possible ways of being and not a reproducing of the already given. Second, disclosing is always a kind of self-disclosing as well. Being in the world as entanglement shows itself in our understanding as caring, how a connection between facticity and possibility is continuously enacted through Dasein, within a world not of Dasein's control.

Now, the participants in the post-human debate in our case can, roughly, be seen as expressing two different kinds of self-understandings connected to the disclosing of the post-human figure as depending on a being in the world. They are expressed, on the ontic level, as the negative and positive conceptual determination of what is implied in the post-human ontology, respectively, and as an ontological response, a self-disclosing, in the reaction to the post-human ontology as consisting of different understandings of what being in the world means. Besides the already quoted negative conceptual determination of post-humanism, Badmington (2004, p. 1349) claims that the 'anthropocentric discourse both holds sway ... and sways wildly from itself, with which a "critical posthumanism" ... must now endlessly engage'. Eradicating or negating any element of humanism seems to be the sole objective for post-humanist thinking. In much the same vein is Braun's (2004b, p. 1354) claims that 'The human was post from the beginning' and should be understood, not as consisting of some capacity of transcendence or as an object of recovery, but 'as in the middle of multiple becomings, always an effect of politics, rather than that which grounds politics'. Being in the world is understood here as being an effect of rather than partaker of the disclosing of being. Hence, for both Badmington and Braun being in the world as a post-human "figure" is predominantly understood as a negative determination by denying any activity on part of the human being. What matters is that the human being is not in control. Both express a denial, then, a denial of the responsibility disclosed above as part of the human caring. Their response to the questioning of the post-human ontology, then, comes very close to a full-blown defeatism regarding possible active human participation in any ontology. A further consequence is the refusal of letting the disclosed being in the world be a part of Dasein's future support of the disclosing of being, or to put it in other words, a declining of understanding the possibility of a future space of researching post-humanism as connected to a human concern and responsibility.

Murdoch and Whatmore, however, both express a cautious but still positive determination of the human being. In Murdoch's (2004, p. 1357) words, 
'the posthumanist condition can best be understood by working through humanist discourse', and at the same page he ends up addressing the difficulty in articulating the entanglement between humanism and post-humanism by assuming a we for which he speaks. This we develop forms of critical reflection 'as we seek to navigate our way through the complex relations that comprise our posthuman world' (Murdoch 2004, p. 1359). Murdoch's claim of the interrelatedness of the human and the post-human, then, comes close to conceiving the implications of being in the world, and working through the humanist discourse using a critical reflection sounds close to a responsible responding towards phenomena of which we are part, but not always in control. As already stated, Whatmore (2004, p. 1361) prefers " "more-than-human" to the "posthuman"; a signature that conjures a different kind of historicity' and demonstrates that 'one never arrives at a time/ place when the human was not a work in progress'. A work in progress, developing how humans understand themselves and their surroundings, accepts uncertainty as a continuous working towards being at home, trying to restore a grip on the world and ourselves in a responsible fashion. A different kind of historicity can perhaps be disclosed here, one in which Dasein partakes but is not in control of. Both Murdoch and Whatmore, then, express a concern for the place of the human in the post-human ontology while accepting that this human and this place are dynamically related. The dawning responsive responsibility appears in the effort of or caring for understanding the implications of what is disclosed in post-humanity as an expression of being in the world; that the disclosed matters come out in the uncertainty of a research practice trying to project a new space for carrying on research as a critical reflection, or a new kind of historicity.

To sum up, what is disclosed here, then, is that the questioning of the human being in posthumanism indicates more of a culmination of humanism, in the sense of humanism's questioning of itself, than a break. Furthermore, the answers given reflect two distinct ways of responding to the sense of not being at home in the world, of coping with the uncertainty. The first was a defeatist refusal to recognize any active human partaking in the disclosing of being, thus accepting no particular place for the human being other than what is given. The second, a more positive but cautious questioning of the place left for the human as a non-essentialist and entangled being in and with the world. Because of the expressed cautiousness, humbleness was disclosed through the articulation, or telling, of an acceptance of the entanglement within a more than human, but still human, ontology. Overall, then, the participants in the debate are concerned, in Heidegger's words they express a caring, by asking for the place of a non-substantialist and entangled human being, like Dasein, in a post-human ontology and answering it in a negative and positive fashion, respectively.

\section{Closing}

Accepting that post-humanism is a matter of questioning of ontology and, furthermore, that this makes an interpretation appropriating Heidegger's posing of the question of being highly relevant, this article has indicated three things. First, if the generous interpretation of Heidegger is allowed, then most of what is implied in post-humanism - the human being not in control, a non-substantialist conception of human being and a primary entanglement with other entities in the world - is already described and thought through by Heidegger in Being and Time. Human, post-human or non-human as discovered entities and conceptual determinations, whether positive or negative, are meaningful or become meaningful against the background of a more fundamental disclosing only.

Second, this disclosing is a self-disclosing as well, in the sense that we as researchers are part of the phenomena disclosed. Indications of this, it was claimed, was expressed in the sense of not being at home in the post-human ontology by claiming - or say, perhaps, responding responsibly to - a place for the human as more than human, or recovering, or saving something human.

Third, understanding the post-human figure through Heidegger's thinking has thereby sharpened the understanding of what is implied in appealing to post-humanity as a condition and it has done so in several senses. One consequence of appealing to post-humanity which has been brought out through the analysis above is the difference between the defeatist and non-defeatist versions of understanding human being. Claiming human being as non-substantialist and entangled with other entities is not tantamount to claiming human being as a pure effect or as being reactive, it is instead reconceiving the possibility of human agency in the light of other agencies and expressing a human concern for the interaction of these different agencies. This would be in line with, for example, non-representational 
theory, but understood as disclosing and expressing what human agency, as an entanglement with the world, is all about, and not as moving beyond human being.

Another consequence brought out by the analysis above, is the importance of understanding the historical background of what is allegedly claimed as new conceptual breakthroughs. Much of the resurgent literature on Heidegger and geography takes this form, claiming Heidegger as a significant voice and precursor for current discussions and issues, and as shown above, also for post-humanism. Heidegger's version of post-humanism turned out to be more complex, argumentatively sophisticated and compelling than the contemporary versions. Furthermore, it helps framing what is and can be meaningful within these contemporary versions and thereby establishing a post-humanist informed, but still human geography.

Where does that leave us, then? I will end with a brief indication of possible answers to this question, not intended as conclusive answers but as opening up further discussion. To start with, it leaves us with the condition of accepting the possibility of continuously correcting our scientific practices as part of disclosing being. Furthermore, it should be recognized that the value of the phenomena disclosed through our scientific practices exists in their theoretical and practical import, that is, how these phenomena matter for us and inform our future dealings with the objects of our attention (including ourselves). Hence, instead of denigrating the human, even if the, most likely correct, critique of the predominance of the human at the expense of other entities is accepted, the value of the disclosed phenomena is still of a $h u$ man concern, of clarifying, intervening or showing some directions in different situations, as part of our understanding of being. Focusing on the sense of questioning as the main feature, then, the debate of post-humanism appears more as an expression of a (human) concern for understanding being, including human being, than leaving the human conception behind.

It also implies that further debate on what posthumanism can mean for us is important. Posthumanism is, as the debate and the analysis of it shows, an occasion for initiating a discussion of what it means to be human and what kind of future we will be part of instigating, as Kompridis (2009, p. 23) claims, and, furthermore, how a responsible responding can inform our part. Conceiving the human being in a negative fashion or as a pure effect as some post-human protagonists have done faces the fear of succumbing to impotence and despair debarring any effort in claiming a place for the human being as a matter of human concern. As Kompridis (2009, p. 25) claims, then, the importance is tied to "how to redisclose the rich field of connections between persons and things, showing their mutual interdependence and imbrication'. Even though Kompridis' context, here, is the Kantian distinction between persons and things, it can safely be assumed that this rich field pertains to entities other than things, as an important part of the post-human context as well. Redisclosing this field, however, presupposes a certain humbleness on the part of humans, a humbleness demanding openness to the diversity of these connections, caring for what and how being(s) matters within the world we live. So, yes, we care (or should care) about post-humanism, as disclosing an understanding of ourselves as human beings and as part of a bigger whole, namely, being in the world. And, to reiterate, because this is a very human thing to do.

\section{Acknowledgements}

Thanks to Professor Iain Thomson for clearing up some matters and the editors for some very helpful comments. Needless to say the usual disclaimers apply.

\section{Notes}

1. In this sense, as Haugeland (1999, p. 48) claims, Dasein is not individual persons like each geographer scientist, nor something they all share as a group, but the different engagements, theoretical and practical deliberations developed and realized through and by these scientists' practices of engaging with whatever it is they are engaging with.

2. No Heidegger exegesis is pretended here, merely a suggestion that Heidegger's thinking about being will have a bearing on the debate on post-human ontology and what this bearing could be. Hence, most of Heidegger's innovative and thoughtful terminology will, to avoid what might seem like a terminological esotericism for readers unfamiliar with Heidegger, not be used in the following. Despite this, readers familiar with Heidegger will, hopefully, recognize his thinking behind the following descriptions.

3. Another example of a preoccupation with categorizations is Wolfe's geometrical schema showing a motley crew of mixed human and post-human figures (Wolfe 2009, p. 125). Despite not being exhaustive, Wolfe's schema comes very close to being instructive in laying out the frame in which post-humanism is meaningful. Hence, he ends up non-intentionally making a representation of how the world is supposed to be conceived, rather than exploring possible ways of being as originally intended.

4. See von Hermann (1987) for a very thorough commentary and 
exposition of the chapter on the question on the meaning of being in Being and Time.

5. It should be noted that being in the world is not pictured as some kind of containment, where one container, the world, keeps something, the human, in it. This would, implicitly, posit both the world and the human as two separate and already given realms subsequently related, whereas Heidegger's notion is the opposite. Any conceptualization of a world or a human as separate from each other grows out of a previous entanglement between these. Hence, being in, is more like being in motion or being in love. A human being in love experiences the world as attuned to this being in love and not as a world apart. The related notion of entanglement, though, might wrongly be seen as reinforcing a sense of two separate entities being co-joined. Hence, a better term might be in-tanglement, emphasizing the entanglement as part of being in the world itself. Entanglement will be used the rest of the article, however, but in the $i n$-tangled sense.

6. Being is, of course, predicated on them, as when it is said, 'This bishop is red'. Heidegger's point is, however, that this predicating (along with the two other meanings of "to be" - as existence, and identity) only makes sense within a previous understanding of which bishop is talked about, what red is, and so on.

7. World is used generically here, as denoting the ontological structure of the "practical intelligibility of things, in virtue of which we can find our way about in any particular world, make use of things, and act in a way that has both purpose and point' (Carman 2003, p. 133). Being able to play chess might have a bearing on engaging in other practices and worlds than chess-related kinds, just like engaging in other kinds of activities (game-like or not, like military strategy), might help understanding the world of chess.

8. Heidegger, of course, has a lot more to say about responding, or sofindingness (Befindlichkeit by Heidegger) as Haugeland calls it, and telling (Rede by Heidegger) (see Haugeland 1999, p. 52). It should be noted that responding does not exclude physical responding per se, as developed by Merleau-Ponty (1962) for example, but Heidegger does not unfold this. The same applies for telling, since telling apart might be exemplified by the physical gesture of pointing to something, or picking something up, as well as determining conceptually what is what. Sofindingness and telling are both connected to Dasein's making of distinctions as being in the world (for example, moving this piece since it feels right). These distinctions express both participation, as entanglement, in factical modes of being, and an anticipation of possible modes of being, as we will see later.

9. The German philosopher Walter Schulz claims, in a now classical article (Schulz [1953-1954] 1994), that this idea of Dasein's support in the disclosing of being, Heidegger never leaves. Schulz emphasizes that it is very easy to (mis-)interpret this in a wrong subjectivist fashion, as if the being is dependent upon Dasein only. If this were the case, the result would be a re-establishing of some sort of exceptionalist idea of a subject/ substance on the basis of which another substance, being, could then be explained. Again, that is not the case! The point is, rather, that the disclosing of being is of a human concern, in the sense that disclosing is connected to the openness of Dasein's way of comporting itself towards the world. Schulz ([19531954] 1994, p. 106), furthermore, notes that some interpreters of the late Heidegger's philosophy 'understand Being as it appears in the late writings, as if it is separate from Dasein, and then pronounce as subjectivism the view that this precedence of Being, as a capacity of being in itself, is not acknowledged'. The interpretation of Being and Time put forth in this article is carried out in the spirit of Schulz' interpretation, expressing Dasein's role, among other entities, in disclosing being, but without identifying this role as either subjectivist, humanistic or post-humanistic beforehand. That would be bypassing the fundamental entanglement of Dasein and the world, transforming an ontological condition (of Dasein's role) into an ontic fact (of being exactly like this, or this).

10. Translation, BAC.

11. The Heidegger expert will have realized by now, that this article will be fairly silent on the time aspect of Being and Time. That is on purpose, both because it will increase the length of this article considerably and because it would not affect the main argument, but only supply it. Temporality is, in the end, what brings unity to the structure of caring - responsive responsibility.

12. One example from within the post-humanist's context is Haraway's discussion (Gane 2006, p. 142; see also Haraway 2007) of how Derrida's cat discloses to Derrida that he is naked, the import being that the disclosing is not instigated by Derrida, thus not of his control, but nevertheless still significant. However plain this example might be, it still shows that disclosing and self-disclosing through the caring of Dasein is not a question of Dasein being in control. Rather, it is more like Rouse's reconfiguration of a situation as a disclosure through the exchanges between different participants in this situation. But as Haraway also says in the interview (Gane 2006), she is not quite sure whether the cat cares about Derrida's nakedness. Hence, she is also indirectly saying that caring, in the sense we are speaking about here, pertains primarily to the human being, as the support needed for discoing being.

\section{Bo Allesфe Christensen}

Department of Agroecology and Environment

Faculty of Agricultural Sciences

Aarhus University

Blichers Allé 20, Postboks 50

DK-8830 Tjele

Denmark

Email:BoA.Christensen@agrsci.dk

\section{References}

APPLEBY, J. (2010): 'Man and other beasts', New Humanist 25 (2): $36-40$.

BADMINGTON, N. (2004): 'Mapping posthumansim', Environment and Planning A 36 (8): 1344-1351.

BRAUN, B. (2004a): 'Querying posthumanisms', Geoforum 35 (3): $269-273$.

BRAUN, B. (2004b): 'Modalities of posthumanism', Environment and Planning A 36 (8): 1352-1355.

CADMAN, L. (2009): 'Life and death decisions in our posthuman(ist) times', Antipode 41 (1): 133-158.

CAPOBIANCO, R. (2005): 'Heidegger's turn toward home: on Dasein's primordial relation to Being', Epoché 10 (1): 155-173.

CAPUTO, J. D. (1982): 'Hermeneutics as the recovery of man', Man and World 15 (4): 343-367.

CARMAN, T. (2003): Heidegger's Analytic: Interpretation, Discourse, and Authenticity in Being and Time. Cambridge University Press, New York.

CASTREE, N. and NASH, C. (2004): 'Introduction: posthumanism in question', Environment and Planning A 36 (8): 1341-1343.

CASTREE, N. and NASH, C. (2006): 'Posthuman geographies', Social and Cultural Geography 7 (4): 501-504. 
CASTREE, N., NASH, C., BADMINGTON, N., BRAUN, B., MURDOCH, J. and WHATMORE, S. (2004): 'Mapping posthumanism: an exchange', Environment and Planning A 36 (8): 1341-1363.

CERBONE, D. R. (1995): 'World, world-entry, and realism in early Heidegger', Inquiry 38 (4): 401-421.

CLEGG, J. W. (2010): 'Uncertainty as a fundamental scientific value', Integrative Psychological and Behavioral Science 44 (3): 245-251.

DASTUR, F. (2000): 'The critique of anthropologism in Heidegger's thought', in FAULCONER, J. E. and WRATHALL, M. A. (eds): Approprating Heidegger. Cambridge University Press, Cambridge, pp. 119-134.

ELDEN, S. (2005): 'Contributions to geography? The spaces of Heidegger's Beiträge', Environment and Planning D: Society and Space 23 (6): 811-827.

GANE, N. (2006): 'When we have never been human, what is to be done? Interview with Donna Haraway', Theory, Culture and Society 23 (7-8): 135-158.

GRONDIN, J. (2005): 'Why reawaken the question of Being?', in POLT, R. (ed.): Heidegger's Being and Time: Critical Essays. Rowman and Littelfield, Lanham, MD, pp. 15-31.

HABERMAS, J. (1989): 'Work and Weltanschauung: the Heidegger controversy from a German perspective', Critical Inquiry 15 (2): 431-456.

HANNAH, M. G. (2013): 'Attention and the phenomenological politics of landscape', Geografiska Annaler: Series B, Human Geography 95 (3): 235-250.

HARAWAY, D. J. (2007): When Species Meet. University of Minnesota Press, Minneapolis, MN.

HARRISON, P. and WYLIE, J. (2011): 'Human remains: the place of the human in a post-human world', Track Policies, 4th Nordic Geographers Meeting, Roskilde, 24-27 May [online]. URL http://ruconf.ruc.dk/index.php/ngm/ngm2011/schedConf/trackPolicies [accessed 12 January 2013].

HAUGELAND, J. (1999): 'Truth and finitude: Heidegger's transcendental existentialism', in WRATHALL, M. and MALPAS, J. (eds): Heidegger, Authenticity, and Modernity: Essays in Honour of Hubert L. Dreyfus, vol. 1. MIT Press, Cambridge, MA, pp. 43-77, 350-352.

HAUGELAND, J. (2013): Dasein Disclosed: John Haugeland's Heidegger. Harvard University Press, Cambridge, MA.

HEIDEGGER, M. (1927): Sein und Zeit. Niemeyer, Tübingen.

HEIDEGGER, M. (1962): Being and Time. Harper and Row, New York.

KOMPRIDIS, N. (2009): 'Technology's challenge to democracy: what of the human?', Parrhesia 8: 20-33.

LATOUR, B. (1993): We Have Never Been Modern. Harvard University Press, Cambridge, MA.

MALPAS, J. (2006): Heidegger's Topology: Being, Place, World. MIT Press, Cambridge, MA.
MERLEAU-PONTY, M. (1962): Phenomenology of Perception. Routledge \& Kegan Paul, London.

MURDOCH, J. (2004): 'Humanising posthumanism', Environment and Planning A 36 (8): 1356-1359.

OLWIG, K. R. (2013): 'Heidegger, Latour and the reification of things: the inversion and spatial enclosure of the substantive landscape of things - the Lake District case', Geografiska Annaler: Series B, Human Geography 95 (3): 251-273.

PADDOCK, T. (2004): 'Gedachtes Wohnen: Heidegger and cultural geography', Philosophy and Geography 7 (2): 237-249.

RAE, G. (2010): 'Re-thinking the human: Heidegger, fundamental ontology and humanism', Human Studies 33 (1): 23-39.

ROUSE, J. (1999): 'Truth, scientific understanding, and Haugeland's existential ontology', Philosophical Topics 27 (2): $149-176$.

ROUSE, J. (2002): How Scientific Practices Matter: Reclaiming Philosophical Naturalism. University of Chicago Press, Chicago.

ROUSE, J. (2005): 'Heidegger on science and naturalism', in CUTTING, G. (ed.): Continental Philosophy of Science. Blackwell, Oxford, pp. 123-141.

SAYER, A. (2011): Why Things Matter to People: Social Science, Values and Ethical Life. Cambridge University Press, Cambridge.

SCHULZ, W. ([1953-1954] 1994): 'Über den philosophiegeschichtlichen Ort Martin Heideggers', in PÖGGELER, O. (ed.): Heidegger. Perspektiven zur Deutung seines Werkes. Ergänztes Ausgabe. Beltz Athenäum Verlag, Weinheim, pp. 95-139.

SIMONSEN, K. (2013): 'In quest of a new humanism: embodiment, experience and phenomenology as critical geography', Progress in Human Geography 37 (1): 10-26.

THOMSON, I. (2004): 'Heidegger's perfectionist philosophy of education in Being and Time', Continental Philosophy Review 37 (4): 439-467.

THRIFT, N. (2008): Non-Representational Theory. Space, Politics, Affect. Routledge, London.

von HERMANN, F.-W. (1987): Hermeneutische Phänomenologie des Daseins. Eine Erläuterung von 'Sein und Zeit', Bd. I: 'Einleitung: Die Exposition der Frage nach dem Sinn von Sein'. Klostermann, Frankfurt am Main.

WHATMORE, S. (2002): Hybrid Geographies: Nature, Cultures, Spaces. Sage, London.

WHATMORE, S. (2004): 'Humanism's excess: some thoughts on the "post-human/ist" agenda', Environment and Planning A 36 (8): 1360-1363.

WOLFE, C. (2009): What is Posthumanism? University of Minnesota Press, Minneapolis, MN. 